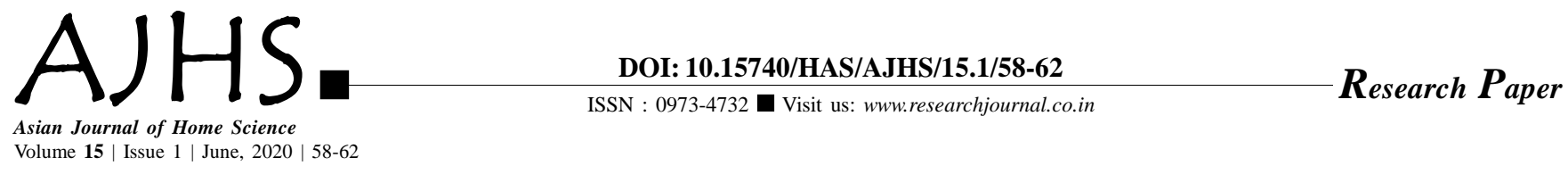

\title{
Assessment of work life balance among female entrepreneurs
}

Neha Rai and U.V. Kiran

See end of the paper for authors' affiliations

Neha Rai

Department of Human

Development and Family

Studies, School for Home

Science, Babasaheb Bhimrao

Ambedkar University, Vidya

Vihar, Raibareli Road, Lucknow

(U.P.) India

Email : neharai331@gmail.com

Received: 04.02.2020; Revised: 11.03.2020; Accepted: 25.04 .2020

ABSTRACT : Aim : The main purpose of the study is to analyze assessment of work life balance among female entrepreneurs in Lucknow city. Methodology: The Cross- sectional research design was used for the study. This study was carried out on sample women entrepreneurs from Lucknow city. A total of 80 respondents were selected from Lucknow city. The sample comprised of three categories of women entrepreneurs including entrepreneurs from beauty parlour, business outlet and catering service. Multistage random sampling technique was used for the study. Random sampling technique was used to select the sample. Results: The result of this study shows, working women executives were having difficulty in balancing their work life. Working women has tries to give their best for family and at work. Among get the three categories of female entrepreneurs selected for the study all the three professionals had problem in balancing their family life and work life due to pressure at work and competitive environment. Conclusion: The findings emphasised entrepreneurship being a global concept contributes for economic development of the country. Economic empowerment is the major goal of women to take up any entrepreneurial activity. They due to use their potential skills in establishing and controlling their own terms and activities. Women through their enterprises helps in providing employment to the unemployed youth and skilled labour, aids in innovation and further at large the National development. Goal orientation to various sections of the society and clarity to the policy makers, also are provided by these women entrepreneurs. They get act as role models, but they can excel only when they are able to harmonise work life.

KEY WORDS: Women entrepreneurs, Work life balance, Managing work life balance

- HOW TO CITE THIS PAPER : Rai, Neha and Kiran, U.V. (2020). Assessment of work life balance among female entrepreneurs. Asian J. Home Sci., 15 (1) : 58-62, DOI: 10.15740/HAS/AJHS/15.1/58-62. Copyright@ 2020: Hind Agri-Horticultural Society. 